\title{
III. On the nature and construction of the sun and fixed stars
}

\section{William Herschel LL.D. F.R.S.}

To cite this article: William Herschel LL.D. F.R.S. (1799) III. On the nature and construction of the sun and fixed stars, Philosophical Magazine Series 1, 5:19, 222-232, DOI:

10.1080/14786449908677144

To link to this article: http://dx.doi.org/10.1080/14786449908677144

曲 Published online: 18 May 2009.

Submit your article to this journal $\sqsubset \pi$

Џ Article views: 4

Q View related articles $\asymp$ 


\section{$\left[\begin{array}{ll}222 & ]\end{array}\right.$}

III. On the Nature and Conftruction of the Sun and Fixed Stars. By. William Herschel, LL.D.F.R.S.

[Concluded from Page 123.]

$I_{T}$

$T$ will now be exfy to bring the refult of thele obfervations into a very narrow compals. That the fun has a very extenfive atmoofphere cannot be dounbteil ; and that this atmofpliere comffts of various elaffic fluids, that are more or lefs lucid and tranfpareitit, and of thich the lueid one is that which furnifhes us with light, feems allo to be fully eftablithed by all the phxnomern of its fpots, of the faculat, and of the lncid furface itfetf. There is no kind of variety in thefe appearances but what may be accounted for with the greateft facility, from the continual agitation which, we may eafily conceive, mitt take place in the reglons of fuch extenfive elátlc fư fds.

It will be-neceffary, however; to be a lfttle more particular as to the manner in which I fuppofe the lucid fluid of the fun to be 'generated in 'is' atmofphere. An analogy that may be drawir from the generation of cloutds in our own atmofphere, fcems to be a very proper one, and fulf of inftruction. Our clouts are probably deconnofitions of fome of the elaftic fluids of the atmofphere itfelf, when fich natural caufs's, as in this grand chemical laboratory are generally at work, at upon them : we may therefore adnit, that in the very extenfive atmofphere of the fun, from caufes of the fame nature, fimilar phænomena will take place; but with this difference, that the contmual and very extenfive decompofitions of the ela'tic thuids of the fury are of a phofphoric nature, and attended with lucid appearances, by giving out fight.

If it thonld be objected, that fuch violent and unremitting decompofitions would exhanit the fun, we may recur again to cur andlogy, which will furnifh us with the following reReetions. The extent of our own atmofphere, we fee, is ftill preferved, notwithftanding the copious decompofitions of its fluids in clouds and falling rain; in flathes of lightning, in meteors, and other luminous phænomena; becaufe there are frefls fupplies of elaftic vapours continually afcending to make 
good the wafte occafioned by thofe decompofitions. But it may be urged, that the cafe with the decompolition of the elaftic fluids in the folar atmofphere would be very different, fince light is emitted, and does not return to the fun, as clouds do to the earth when they defcend in thowers of rain. To which I anfwer, that, in the decompofition of phofphoric fluids, every other ingredient but light.may alfo return to the body of the fun. And that the emiffion of light muft wafte the fun, is not a difficulty that can be oppofed to our hypathefis : for, as it is an evident fact that the fun does emit light, the fame objection, if it could be one, would egutally militate againft every other atignable way to account for the phænomenon.

There are, moreover, confiderations that may leffen the preffure of this alledged dificulty. We know the exceedizg fubtilty of light to be fuch, that in ages of time its emanation from the fun capnot very fenfibly leffen the fize of this great body. To this may be added, that, very poffibly, there may alfo be ways of reftoration to compenfate for what is loft by the emiftion of light, though the manner in which this ean be brought about fhould not appear to us. Many of the operations of Nature are carried on in her great laboratory which we cannot comprehend, but now and then we fee fome of the tools with which the is at work. We need not wonder that their conftruction fhould be fo fingular as to induce us to confers our ignorance of the method of employing them, but we may reft affured that they are not a mere lufus naiure, I allude to the great number of fmall telefcopic comets that have been obferved, and to the far greater number fill that are probably much too fmall for being noticed by our moft diligent fecarchers after them. Thofe fix, for inftance, which my fifter has difcovered, I can from examination affirm, had not the leaft appearance of any folid nucleus, and feemed to be mere collections of vapours condenfed about a centre, Five more, that I have alfo obferved, were nearty of the fame nature. This throws a myltery over their deftination, which feems to place them in the allegorical view of tools, probably defigned for fone falutary purpofes to bo wrought by them; and, whether the reftaration of what is 
loft to the fun by the emiffion of light, the poffibility of which we have been mentioming above; may not be one of thefe purpofes, I thall not prefume to determine. The motion of the comet, difcovered by Mr. Meffer in June I770; plainly indicated how much its orbit was liable to be changed by the perturbations of the planets; from which, and the little agreement that can be found between the elements of the orbits of all the comets that have been abferved, it appears clearly that they may be directed to carry their falutary influence to any part of the heavens.

My hypothefis, however, as before obferved, does not lay me under any obligation to explain how the fun can fuftain the wafte of light, nor to thew that it will fuftain it for ever; and I fhould alfo remark that, as in the analogy of generating clouds, I merely allude to their production as owing to a decompufition of fome of the elaftic fluids of our atmofphere, that analogy, which firmly refts upon the fact, will not be lefs to my purpofe, to whatever caufe thefe clouds may owe their origin. It is the fame with the lucid clouds, if I may fo call them, of the fun. They plainly exift, becaufe we fee them; the manner of their being generated may remain an hypothefis-and mine, till a better can be propoled, may ftand good; but, whether it does or not, the confequences I am going to draw from what has been faid will not be affected by it.

Before I proceed I thall only point out, that, according to the above theory, a dark fpot in the fun is a place in its atmofphere which happens to be free from luminous decompofitions; and that faculie are, on the contrary, more copious mixtures of fuch fluids as decompofe each other. The penumbra, which attends the fpots, being generally depreffed, more or lefs, to about half way between the folid body of the fun and the upper part of thofe regions in which luminous decompofitions take place, mult of courfe be fainter than other parts. No fpot favourable for taking meafures having lately been on the fun, I can only judge, from former appearances, that the regions in which the luminous folar clouds are formed, adding thereto the elevation of the faculx, cannot be lefs than $18+3$, nor much more than 2765 
miles in depth. It is true that in our atmofphere the extent of the clouds is limited to a very narrow compafs; but we ought rather to compare the folar ones to the luminous decompofitions which take place in our aurora borealis, or luminous arches which extend much farther than the cloudy regions. The denfity of the luminous folar clouds, though very great, may not be exceedingly more fo than that of our curora borealis. For, if we confider what would be the brilliancy of a fpace two or three thoufand miles deep, flled with fuch corrufcations as we fee now and then in our atmofphere, their apparent intenfity, when viewed at the cliftance of the fun, might not be much inferior to that of the lucid folar fluid.

From the luminous atmofphere of the fun I proceed to its opaque body, which, by calculation from the power it exerts upon the planets, we know to be of great folidity; and from the phrnomena of the lark fpots, many of which, probably on account of their high fituations, have been repeatedly feen, and otherwife denote inequalities in their level, wo furmife that its furface is diverfified with mountains and vallies.

What has been faid enables us to come to fome very important conclufions, by remarking, that this way of confidering the fun and its atmofphere removes the great diffimilarity we have hitherto been ufed to find between its condition and that of the reft of the great bodies of the folar fyftem.

The fun, viewed in this light, appears to be nothing elfe than a very eminent, large, and lucid planet, evidently the firft, or, in ftrictnefs of fpeaking, the only primary one of our fyftem, all others being truly fecondary to it. Its fimilarity to the other globes of the folar fyftem with regard to its folidity, its atmofphere, and its diverfified furface, the rotation upon its axis, and the fall of heavy bodies, leads us on to fuppofe that it is moft probably alfo inhabited, like the reft of the planets, by beings whofe organs are adapted to the peculiar circumftances of that vaft globe.

Whatever fanciful poets might fay in making the fun the abode of bleffed fpirits, or angry moralifts devife in pointing it out as a fit place for the punithment of the wicked, it does 
not appear that they had any other foundation for their affertions than mere opinion and vague furmife; but now $I$ think myfelf authorifed, upon aftronomical principles, to propofe the fun as an inhabitable world; and am perfuaded that the foregoing obfervations, with the conclufions I have drawn from them, are fully fufficient to anfwer every objection that may be made againft it.

It may, however, not be amils to remove a certain difficulty, which arifes from the effect of the fun's rays upon our globe. The heat which is here, at the diftance of 95 millions of miles, produced by thefe rays, is fo confiderable, that it may be objected, that the furface of the globe of the fun itfelf mutt be fcorched up beyond all conception.

This may be very fubftantially anfwered by many proofs drawn from natural philotophy, which thew that heat is produced by the fun's rays onty when they act upon a calorific medium; they are the canfe of the production of heat, by uniting with the matter of fre which is contained in the fubftances that are heated; as the collifion of flint and fteel will inflame a magazine of ganpowder, by putting all the latent fire it contains into action. But an inftance or two of the manner in which the folar rays produce their effet, will bring this home to our moft common experience.

On the tops of mountains of a fufficient height, at an atitude where clouds can very feltom reach to thelter them from the direct rays of the fun, we always find regions of ice and fnow. Now, if the folar rays themfelves conveyed all the heat we find on this globe, it onght to be hotteft where their couffe is leaft intermpted. Again, our aëronauts all confirm the coldnefs of the apper regions of the atmofptrere; and fince, therefore, even on our earth, the heat of any fituation depends imon the aptricfs of the metian to yield to the impreffion of the folat rays, we have only to admit, that, on the fun itfelf, the elaftic fuids compofing its atmofphere, and the matter on its furface, are of fuch a nature as not to bee capable of any exceffive affection from its own rays : and, indeed, this feems to be proved by the copious emiffion of them ; for if the elaftic ftuids of the atmofphere, or the matter contained on the furface of the fun, wore of fuch a nature 
as to admit of an eafy, chemical combination with its rays, their emiffion would be much impeded.

Another well known fact is, that the folar focus of the largelt lens, thrown into the air, will occafion no fentible heat in the place where it has been kept for a confiderable time, although its power of exciting combuttiou, when proper bodies are expofed, fhould be fufficient to fufe the moft refractory fubftances *.

It will not be neceffary to mention other objections, as I can think of none that may be made but what a proper confideration of the foregoing obfervations will eafily remove; fuch as may be urged from the difimilarity between the luminous atmofphere of the fun and that of our globe will be touched upon hereafter, when I confider the objections that may be affigned againft the moon's being an inhabitable fatellite.

I thall now endeavour, by analogical rcafonings, to fupport the ideas I have fuggrefted concerning the conftuction and purpofes of the fun; in order to which it will be neceffary to begin with fuch arguments as the nature of the cafe will admit, to hew that our moon is probably inhabited. This fatellite is of all the heavenly bodies the neareft, and therefore mott within the reach of our telefcopes: accordingly we find, by repeated infpection, that we can with perfect confidence give the following account of it:-

It is a fecondary planet, of a confderable fize; the furface of which is diverffied, lilie that of the earth, by mountains and vallies. Its fituation with refpect to the fun is much like that of the earth, and, by a rotation on its axis, it enjoy's an agreeable variety of feafons, and of day and night. To the moon our globe will appear to be a very capital fatellite, undergoing the fame regular changes of illuminations as the moon does to the earth. The fun, the planets, and the ftarry conftellations of the heavens, will rife and fet there as they do here; and heavy bodies will fall on the moon as they do

* The lubjact of light and heat has been very ab'y difcuffed by Mr. De Luc, in his excellent work, lder fur la Mitrorologie, Tome I. part 2. chap. 2. fection 2. De la Nature cin Fen; and Tome II parc 3. chap. ?

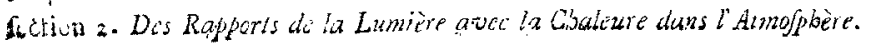


on the e irth. There feems only to be wanting, in order to complete the analogy, that it fhould be inhabited like the earth.

To this it may be objected, that we perceive no large feas in the moon: that its atmolphere (the exiftence of which has even been doubted by many) is extremely rare, and unfit for the purpofes of animal life: that its climates, its feafons, and the length of its days, totally differ from ours : that without denfe clouds (which the moon has not), there can be no rain; perbaps no rivers, no lakes. In thort, that, notwithftanding the fimilarity which has been pointed out, there feems to be a decided difference in the two planets we have compared.

$\mathrm{My}$ anfwer to this will be, that that very difference which is now objected will rather ftrengthen the force of my argument than lefen its value: we find, even upon our globe, that there is the moft ftriking diference in the fituation of the creatures that live upon it. While man walks upon the ground, the birds fly in the air, and fifhes fwim in water; we can certainly not object to the conveniences afforded by. the moon, if thofe that are to inhabit its regions are fitted to their conditions as well as we on this globe are to ours. An abfolute, or total famenefs, fuems rather to denote imperfections, fuch as Nature never expoles to our view; and, on this account, I believe the aralogies that have been mentioned fully fufficient to eftablith the high probability of the moon's being inhabited like the carth.

To proceed, we will now fuppofe an inhabitant of the moon, who has not properly confidered fuch analogical reafonings as might induce him to furmife that our earth is inhabited, were to give it as his opinion that the ufe of that great body, which he fees in his neighbourhood, is to carry about his little globe, that it may be properly expofed to the light of the fun, fo as to enjoy an agreeable and ufeful variety of illumination, as well as to give it light by reflection from the fun when direct day-light cannot be had. Suppofe alfo that the inhabitants of the fatclites of Jupiter, Saturn, and the Georgian planet, were to look upon the primary ones, to which they belong, as mere attractive centres, to keep together their orbits, to direct their revolution round the fun, and 
to fupply them with reflected light in the abfence of direct illumination. Ought we not to condemn their ignorance, as proceeding from want of attention and proper reflection? It is very true that the earth, and thofe other planets that have fatellites about them, perform all the offices that have been named for the inhabitants of thefe little globes; but to us, who live upon one of thefe planets, their reafonings cannot but appear very defective, when we fee what a magnificent dwelling-place the earth affords to numberlefs intelligent beings.

Thefe confiderations ought to make the inhabitants of the piancts wifer than we have fuppofed thofe of their fatellites to be. We furely ought not, like them, to fay " the fun " (that immenfe glohe, whofe body would much more than "fill the whole orbit of the moon) is merely an attractive " centre to us." From experience we can affirm, that the performance of the molt falutary offices to inferior planets is not inconfiftent with the dignity of fuperior purpofes; and, in confequence of fuch analogical reafonings, affited by telefcopic views, which plainly favour the fame opinion, we need not hefitate to admit that the fun is richly ftored with inhabitants.

This way of confidering the fun is of the utmolt importance in its confequences. That fars are funs can hardly admit of a doubt. Their immenfe diftance would perfectly exclude them from our view, if the light they fend us were not of the folar kind. Befides, the analogy may be traced much farther. The fun turns on its axis: fo does the ftar Algrol: fo do the ftars called $\beta$ Lyra, $\delta$ Cephei, $n$ Antinoi, - Ceti, and many more; moft probably all. From what other caule can we fo probably account for their periodical changes? Again, our fun has fpots on its furface: fo has the ftar Algol, and fo have the ftars already named, and probably every ftar in the heavens. On our fun thefe fpots are changeable: fo they are on the ftar o Ceti, as evidently appears from the irregularity of its changeable lutire, which is often broken in upon by accidental changes while the general period continues unaltered. The fame little deviations have been obferved in other periodical ftars, and ought to be afcribed 
afcribed to the fame caufe. But if ftars are funs, and funs are inhabitable, we fee at once what an extenfive field for animation opens itfelf to our view.

It is true that analogy may induce us to conclude, that, fince ftars appear to be funs, and funs, according to the common opinion, are bodies that ferve to enlighten, warm, and fuftain a fyftem of planets, we may have an idea of numberlefs globes that ferve for the habitation of living creatures. But if thefe funs themfelves are primary planets, we may fee fome thoufands of them with our own eyes, and millions by the help of telefcopes, when at the fame time the fame analogical reafoning ftill remains in full force with regard to the planets which thefe funs may fupport.

In this place I may, however, take notice, that, from other confiderations, the idea of funs or ftars being merely the fupporters of fyftems of planets, is not abfolutely to be admitted as a general one. Among the great number of very compreffed clufters of ftars $\mathbf{l}$ have given in my catalogues, there are fome which open a different view of the heavens to us. The ftars in them are fo very clofe together, that, notwithftanding the great diftance at which we may fuppofe the clufter itfelf to be, it will hardly be poffible to affign any fufficient mutual diftance to the ftars compofing the clufter, to leave room for crowding in thofe planets, for whofe fupport thefe ftars have been, or might be, fuppofed to exift. It fhould feem, therefore, highly probable that they exift for themfelves; and are, in fact, only very capital, lucid, primary planets, connected together in one great fyftem of mutual fupport.

As in this argument I do not proceed upon conjectures, but have actual obfervations in view, I thall mention an inftance in the clufters No. 26, 28, and 35, VI. clafs, of my catalogue of nebulæ, and clufters of ftars. (See Phil. Tranf. Vol. LXXIX. Part II. p. 25i.) The ftars in them are fo crowded that I cannot conjecture them to be at a greater apparent diftance from each other than five feconds, even after a proper allowance for fuch ftars, as, on a fuppofition of a globular form of the clufter; will interfere with one snother, has been made. Now, if we would leave as nuch room be- 
tween cach of thefe ftars as there is between the Sun and Sirius, we muft place thefe clufters $42 \mathrm{IO}_{4}$ times as far from us as that ftar is from the fun. But, in order to bring down the luftre of Sirius to that of an equal ftar placed at fuch a diftance, I ought to reduce the aperture of my 20 -feet telefcope to lefs than the two-and-twenty hundredth part of an inch; when certainly I could no longer expect to fee any ftar at all.

The fame remark may be made with regard to the number of very clofe double ftars, whofe apparent diameters being alike, and not very fmall, do not indicate any very grest mu tual diftance: from which, however, muft be deducted all thore where the different diftances may be compenfaxted by the real difference in their refpective magnitudes.

To what has been faid may be added, that, in fome parts of the milky way, where yet the ftars are not very fmall, they are fo crowded, that in the year 1792, Aug. 22, I found by the gages that, in $4 \mathrm{I}$ minutes of time, to lefs than 258 thoufand of them had paffed through the field of view of my tekfcope*.

It feems, therefore, upon the whole, not improbable that, in many cafes, ftars are united in fuch clofe fyltems as mot to leave much room for the orbits of planets or comets; and that confequently, upon this account alfo, many ftars, unlefs

The far-gages ran thus:

From $19^{\text {h }} 3.5^{1}$ to $4.9^{\mathrm{h}} \$ \mathrm{I}^{l} 600$ ftars in the field

$1951-1957 \quad 440$

$1957-2012360$

$20 \quad 12-20 \quad 16 \quad 260$

The breadth of the fweep was $2^{\circ} 35^{\text {? }}$, the diameter of the field is', and the mean polar diftance $75^{\circ} 54^{\prime}$. Then let

$F$, be the diameter of the field of view,

$S$, the number of ftars in each fieid,

$B$, the breadth of the fweep, plus $F$,

$\boldsymbol{T}$, the length of the fweep, expreffed in minutes of fpace,

$\phi$, the fine of the mean polar diftance,

$C$, the conftant fraction, $7 \delta_{54}$,

and the fars in thefe four fucceflive fhort fweeps will be found by the expreffion $\frac{B T S_{\phi}}{F^{2} \mathrm{C}}$ equal to 133095.36601 .74866 . 14419. or in all 259981 . 
we would make them mere ufelefs brilliant points, may themfelves be lucid planets, perhaps unattended by fatellites.

\section{POSTSCRIPT.}

The following obfervations, which were made with an improved apparatus, and under the moft favourable circumftances, fhould be added to thofe which have been given. They are decifive with regard to one of the conditions of the lucid matter of the fun.

Nov. 26, 1794. Eight fpots in the fun, and feveral fubdivifions of them, are all equally depreffed.

The fun is mottled every where.

The mottled appearance of the fun is owing to an inequality in the level of the furface.

The fun is equally mottled at its poles and at its equator; but the mottled appearances may be feen better about the middle of the difc than towards the circumference, on account of the fun's fpherical form.

The unevennefs arifing from the elevation and depreffion of the mottled appearance on the furface of the fun, feems in many places to amount to as much, or to nearly as much, as the depreffion of the penumbræ of the fpots below the upper part of the thining fubftance, without including faculæ, which are protuberant.

The lucid fubftance of the fun is neither a liquid nor an elaftic fluid; as is evident, from its not inftantly filling up the cavities of the fpots, and of the unevennefs of the mottled parts. It exilts, therefore, in the manner of lucid clouds fwimming in the tranfparent atmofphere of the fun; or rather, of luminous decompofitions taking place within that atmofphere. 